Yujia Zhai

Boston College

School of Theology and Ministry

\title{
Resurrection and Death \\ From Rabbinic Understandings to the Theology of Edward Schillebeeckx
}

For centuries, Christianity's signature emphasis on overcoming death through believing in Jesus and the resurrection of the dead has overshadowed the meaningful and constructive role of death in human life. ${ }^{1}$ As early as Justin Martyr, Christian theology related to death has become heavily metaphysical and obsessed with the status of the soul after death, such as its immortality and purgation, as well as the nature of the resurrected body. Yet death itself has often been sidestepped. Likewise, considering Jesus and early Christian martyrs, Christian spirituality has traditionally regarded death as the superlative rejection of human sinfulness in this world in order to maintain personal holiness in the next. It is quite concerning that death in Christianity has been understood excessively in light of postmortem resurrection and sanctification but rarely as a human phenomenon in the context of this world. ${ }^{2}$ Therefore, as a student of Christian-Jewish relations and an advocate for Christian-Jewish reciprocity through interreligious learning, I would like to address this concern by exploring the understandings of death in early rabbinic Judaism as recorded in the foundational texts such as the Mishnah and the Talmud. I argue that, despite not acknowledging Jesus's resurrection, rabbinic Judaism can not only speak of resurrection and death in ways that are meaningful for Christians, but also enrich Christian understanding precisely because it approaches resurrection and death from a perspective that is not distinctively Christian. Given that Jesus's resurrection has fundamentally shaped Christian

${ }^{1}$ See John 8:51, for example.

${ }^{2}$ For an overview of Early Christian Fathers' views on death and resurrection, see Terence $\mathrm{L}$ Nichols, "Death and Afterlife in the Christian Tradition," in Death and Afterlife: A Theological Introduction (Grand Rapids, MI: Brazos Press, 2010), 55-66. 
approaches to death, I will first discuss resurrection in order to better illustrate the relationship between understandings of resurrection and rabbinic Jewish understandings of death.

\section{Resurrection in Early Rabbinic Judaism}

It is a very popular assumption that resurrection plays a central role in early rabbinic

Judaism. Two of the most quoted examples of textual supports are as follows:

"For if he were not expecting that those who had fallen would rise again, it would have been superfluous and foolish to pray for the dead."

(2 Maccabees 12:44)

"One has no portion in the world to come who says, "the resurrection of the dead is a teaching which does not derive from the Torah." (Mishnah Sanhedrin 10:1)

While widely quoted, these texts only point to the existence of belief in resurrection; they neither describe the content of this belief nor illustrate the reasoning behind this belief. If the entire Mishnah and Talmud were examined, one would find that the majority of references to resurrection appear in the chapter 10 of Tractate Sanhedrin, a chapter that exclusively focuses on the beliefs regarding the world to come. Not surprisingly, this is also the section where discussions on the eschatological messiah and the messianic age are prevalent. It is one of the very few early rabbinic texts that make dogmatic assertions (i.e. regarding what Jews ought to believe). ${ }^{3}$ Among a variety of arguments for resurrection that appear in this chapter, one type of argument is based on a fortiori reasoning, also known as kal vahomer in Hebrew. An example is "if what was not living, [now] lives, surely what has lived, will live again!"” Another type is scriptural reasoning or, rather, grammatically-based prooftexting. Examples can be easily found in the Talmud such as "Whence is resurrection derived from the Torah? From the verse, 'Blessed

${ }^{3}$ Related comments on consequence of not believing in resurrection in the context of "orthodoxy" can be found also in BT Baba Bathra 16a.

${ }^{4}$ BT Sanhedrin 91a 
are they that dwell in thy house: they shall ever praise thee. Selah.' Not 'praised thee,' but they shall praise thee is stated: thus resurrection is taught in the Torah." ${ }^{5}$

Another type of argument envisions the scene of eschatological judgment and concludes that, since both body and soul are responsible for sinful deeds, they have to be present together for judgment. ${ }^{6}$ These arguments give us a sense of the rabbinic reasoning behind the belief in resurrection. Most notably, the rabbis do not base their arguments for resurrection on a negative understanding of death. This is not to say that the rabbis do not consider death as negative at all, but only that it is unlikely that death primarily compels the rabbis to argue for their belief in resurrection. Indeed, throughout the Talmud and other rabbinic literature around the same time, there is a considerable diversity of opinions regarding whether resurrection will take place to all human beings, and whether resurrection is eternal (i.e. whether there will be death even after resurrection). For example, though Rabbis have great hope in the revival of the holy people and those whom they love the most (e.g. family members), when it comes to the condemned people or even the gentiles outside of the Land of Israel, Rabbis are less sure about how resurrection applies to them:

Our Rabbis taught: "The generation of the flood have no portion in the world to come." [. . .] R. Judah b. Bathyra maintained: "They will neither revive nor be judged, as it is written, 'My spirit will not always enter into judgment with man': [its] teaching [is that they will have] neither judgment nor spirit [in the world to come]. Another meaning of 'My Spirit will not enter etc.': their soul shall not return to its sheath." [But] R. Menahem son of R. Jose said: "Even when the Holy One, blessed be He, restores the souls to the dead bodies, their soul shall grieve them in the Gehenna, as it is written, 'Ye shall conceive chaff ye shall bring forth stubble: your soul, as fire, shall devour you.'” (BT Sanhedrin 108a)

\footnotetext{
${ }^{5}$ BT Sanhedrin 91b. The biblical quote is from Psalm 84:4 (according to NRSV).

${ }^{6}$ See BT Sanhedrin $91 \mathrm{a}-\mathrm{b}$ for the full argument.
} 
Such a diversity of views on the relationship between death and resurrection in rabbinic literature suggests that the rabbinic motivation for arguing for resurrection is primarily rooted not in the absolute necessity for overcoming death but in a holy trust in God's graciousness and providence. $^{7}$

Outside of Sanhedrin, there are a number of non-dogmatic description of resurrection. In Berekhot $26 \mathrm{~b}$ and 33a, which discuss the laws regarding the second section of Amidah $-\mathrm{a}$ core text of Jewish daily blessings — resurrection is associated with rain and dew as signs of God's life-generating power. ${ }^{8}$ Berekhot 58b, recalling Psalm 31, connects resurrection with friendship, as it cites the opinion of R. Joshua b. Levi: "[One who sees a friend again] after a lapse of twelve months he [should] say: Blessed is He who revives the dead." These two examples reveal another dimension of Jewish belief in resurrection, namely resurrection as a vague hope but deeply rooted in the experience of ordinary life of this world, such as loving God's creations and committing to interpersonal relationships.

\section{Death in Early Rabbinic Judaism}

With regard to the understandings of death reflected in the legal materials on burial and mourning practices in the Mishnah and Talmud, Rabbinic Judaism designates various responsibilities of taking care of the dead, most notably burial and mourning. These ritual or semi-ritual acts are rich in meaning beyond simply being legal requirements, as they provide an

${ }^{7}$ For a discussion on the examples of this holy trust in some Talmudic legends recounting the death of sages, see Bruce Chilton and Jacob Neusner, "The Sage's Good Death," in Comparing Spiritualities: Formative Christianity and Judaism on Finding Life and Meeting Death (Harrisburg, PA: Trinity Press International, 2000), 45-67.

${ }^{8}$ Brigitte (Rivka) Kern-Ulmer, "Consistency and Change in Rabbinic Literature as Reflected in the Terms of Rain and Dew," Journal for the Study of Judaism in the Persian, Hellenistic, and Roman Period 26, no. 1 (1995): 65-66. 
opportunity to look into the deep thinking of the rabbinic minds. Here, we shall keep in mind that the principle of "Lex orandi, lex credendi" could apply to non-Christian religions as well.

A basic command of rabbinic burial is that the death should be placed onto the ground as soon as possible. This is understood in light of creation myth as illustrated in Genesis 2:"remember that you are dust, and unto dust you shall return". ${ }^{9}$ The undertone of creation in rabbinic burial is manifested in the post-funeral banquet where participants may experience the strengthening of life through food. ${ }^{10}$ The relationship between the living and the dead continues in a substantial way after death, however, as rabbinic Judaism regards dying as a long-term process corresponding to the natural decomposition of human bodies. During this time, the dead is believed to be capable of feeling through the corpse ${ }^{11}$ capable of being jealous about not being able to participate in living people's activities, ${ }^{12}$ and capable of being pleased with mourners who separate themselves from the living world in order to join in the suffering of the dead. ${ }^{13}$

The dead is ritually separated from the living community through ritual defilement. ${ }^{14}$ Indeed, ritual defilement plays a positive role in keeping a meaningful boundary between divine worship and the realm of the death. Rabbis regard death as the "father of defilements" because

${ }^{9}$ David Charles Kraemer, The Meanings of Death in Rabbinic Judaism (London: Routledge, 2000), 27.

${ }^{10}$ Ibid., 32 .

${ }^{11}$ Ibid., 104; Chilton and Neusner, "The Sage's Good Death," 56. This is due especially to (early) rabbinic Judaism's lack of a uniform and well-established theoretical understanding of the soul as metaphysically independent.

${ }^{12}$ Kraemer, The Meanings of Death in Rabbinic Judaism, 106.

${ }_{14}^{13}$ Ibid., 113.

${ }^{14}$ Ibid., 74-75. I am aware that ritual defilement is an extremely complicated concept event for Jewish scholars, and I am here inevitably running the risk of over-generalization. Nevertheless, ritual defilement in Rabbinic Judaism needs to be addressed, because Christians have too often and too conveniently disregard this aspect of Judaism and/or understood it simply as an impediment to charity as recorded in the Gospel, rather than learning about its positive significance. 
many other kinds of defilements, such as bodily fluids, giving birth, and leprosy, have to do with some sort of loss of life-power and thus are akin to death. While it is true that people with ritual defilements should be temporarily excluded from divine worship in the Temple, ritual defilements also cultivate a sense of one's awareness of being in the proximity of the dead, and therefore strengthens a bonding between the dead and the living ones nearby.

In particular, the living ones—usually close relatives of the dead-participate in the experience of dying through mourning rituals. These ritual practices can transform the participants into a state of being more akin to the dead, as well as separating them from the rest of the living community and their activities. ${ }^{15}$ In addition to penitential acts such as mourning and fasting, a mourner is exempt from a variety of duties, such as cooking and reciting certain prayers during the day, as well as being deprived of many privileges, going to concerts, marital relations, etc., so that he/she can fully dedicate himself/herself to accompanying and imitating the dead. ${ }^{16}$ On Sabbath days and high holidays, the mourner's public life is restored and any public signs of mourning are removed, while the laws of mourning are still in effect in the private sphere. These ritual laws aim to maintain an ordered balance between personal isolation and communal participations; they properly orient the mourner to commit to the living community on behalf of the dead, and to commit to the dead on behalf of the living community. $^{17}$

\footnotetext{
15 Ibid., 88.

${ }^{16}$ Emanuel Feldman, Biblical and Post-Biblical Defilement and Mourning: Law as Theology (New York: Yeshiva University Press, 1977), 82.

${ }^{17}$ Audrey Gordon, "The Psychological Wisdom of the Law," in Jewish Reflections on Death, ed. Jack Riemer (New York: Schocken Books, 1975), 97-101.
} 
The reason why death is worth "participating" for the living is that, in Judaism, death and in fact all sufferings effect atonement. ${ }^{18}$ Even death as a punishment given to a felon atones for the felon's sins. Mourning, therefore, not only allows the mourner to share in the atonement of the dead, but also contributes to the increase of this atonement. ${ }^{19}$ Indeed, rabbinic mourning rituals establish a continuous relationship between the dead and the mourners-a relationship which is radically transformed by death yet never cut off by it. These rituals establish a new channel and a new language for the living to express this continuous relationship with the dead through properly renewed awareness, desires, and commitments.

In conclusion, early rabbinic understandings of death is not overshadowed by the eschatological expectation of the resurrected body. Rather, early rabbinic Judaism conceives death and resurrection via the concrete Jewish experience of human-divine and human-human relationships. The burial and mourning rituals, in particular, illustrate the rabbinic emphasis on the significance of a continuous corporal relationship between the living and the dead here and now in this world, as well as a corporal solidarity of the living with the dead in joint suffering and atonement. Furthermore, the notion of "rituals" in this case does not presuppose a religious realm that is clearly demarcated from secular realm. Rather, rabbinic rituals for the dead has implications on all aspects of life, both the secular and the sacred.

\section{Echoes of Rabbinic Thoughts in the Theology of Edward Schillebeeckx}

Finally, I would like to reflect on the implication and relevance of early Rabbinic Judaism on Catholic theology today, using the theology of Edward Schillebeeckx, a Belgian Catholic theologian known for his contribution to the Vatican II, sacramental theology, and

\footnotetext{
${ }^{18}$ Kraemer, The Meanings of Death in Rabbinic Judaism, 98.

${ }^{19}$ Ibid., 31.
} 
liberation theology, as a test case. My intention is to demonstrate that other religions, especially Judaism —Christianity's closest religious neighbor, are not as theologically and experientially alien to Christians as many people may have presumed, and that an enhanced appreciation of these religions can enrich Christians' own understandings and strengthen their own convictions.

For early Jewish rabbis as for Schillebeeckx, death is neither totally negative nor simply overshadowed by resurrection, but has a revealing and revolutionizing effect on human relationship here and now. Schillebeeckx criticizes the modern people for their avoidance in thinking of what happens to the dead and limiting their commitments to only improving life quality of the survivors. "Belief in the resurrection does not argue away the fact of death; it allows death to be death." ${ }^{20}$ As the ultimate sign of human finitude, death does not terminate the relationship of the dead with God or the living; rather, this relationship is constituted in both "positive experiences and in failure, suffering and death." ${ }^{.1}$ Just as the rabbis situate the experience of resurrection in the experience of rain and dew and friendship, Schillebeeckx situates our experience of death and resurrection in our encounter with "the saving nearness of God" through the experience of God's love for creations. ${ }^{22}$ Just as the rabbis see resurrection as not a necessity due to the negativity of death but as a trust in God's graciousness and justice, Schillebeeckx argues that resurrection is a "surplus of hope" resulted from the dialectical reconciliation of God's absolute saving presence with the experienceable world. ${ }^{23}$ And just as the rabbis canonize burial and mourning rituals as the meaningful expressions of love and care for

${ }^{20}$ Edward Schillebeeckx, God Among Us: The Gospel Proclaimed (New York: Crossroad, 1983), 130-131.

${ }^{21}$ Edward Schillebeeckx, Interim Report on the Books Jesus \& Christ (New York: Crossroad, 1980), 134.

${ }^{22}$ Edward Schillebeeckx, Christ, the Experience of Jesus as Lord (New York: Seabury Press, 1980), 811.

${ }^{23}$ Edward Schillebeeckx, Church: The Human Story of God (New York: Crossroad, 1990), 99. 
the dead in this world, Schillebeeckx insists that "eternal life cannot be seized: only responsible love in the temporal here and now of our human history can give the human and temporal form to God's eternal love. ${ }^{24}$

The fact that Schillebeeckx's discourse on death and resurrection focuses primarily on Jesus does not render rabbinic understandings less relevant. On the contrary, it contributes greatly to our understanding of the Jewishness of Jesus as well as Christianity and Judaism's theological and experiential mutuality. Just as the rabbis envisage mourning rituals as the commitment to conquering of death through solidarity with the dead in suffering and atonement, Schillebeeckx argues that Jesus's assurance in his eternal communion with God and his ability of overcoming suffering and death does not make light of his suffering. Instead, through suffering, Jesus shows solidarity with all his fellow men and women. ${ }^{25}$ And Just as the rabbis regard the ritual commitment to the dead as both sacred and secular, Schillebeeckx asserts that Jesus' death was not a "liturgical cultic ministry set aside from the world, but" [ . . ] a sacrifice as well as a "secular event in a concrete, living situation."26

\footnotetext{
${ }^{24}$ Schillebeeckx, God among Us, 141.

${ }^{25}$ Schillebeeckx, Christ, 800.

${ }^{26}$ Edward Schillebeeckx, The Schillebeeckx Reader, ed. Robert J Schreiter (New York: Crossroad, 1984), 249-250.
} 


\section{Bibliography}

Babylonian Talmud. Accessed Jan 20, 2017. http://www.halakhah.com.

Chilton, Bruce, and Jacob Neusner. "The Sage's Good Death.” In Comparing Spiritualities:

Formative Christianity and Judaism on Finding Life and Meeting Death, 45-67. Harrisburg, PA: Trinity Press International, 2000.

Feldman, Emanuel. Biblical and Post-Biblical Defilement and Mourning: Law as Theology. New York: Yeshiva University Press, 1977.

Gordon, Audrey. "The Psychological Wisdom of the Law." In Jewish Reflections on Death, edited by Jack Riemer, 95-104. New York: Schocken Books, 1975.

Kern-Ulmer, Brigitte (Rivka). "Consistency and Change in Rabbinic Literature as Reflected in the Terms of Rain and Dew." Journal for the Study of Judaism in the Persian, Hellenistic, and Roman Period 26, no. 1 (1995): 55-75.

Kraemer, David Charles. The Meanings of Death in Rabbinic Judaism. London: Routledge, 2000.

Nichols, Terence L. "Death and Afterlife in the Christian Tradition." In Death and Afterlife: A Theological Introduction, 55-66. Grand Rapids, MI: Brazos Press, 2010.

Schillebeeckx, Edward. Christ, the Experience of Jesus as Lord. New York: Seabury Press, 1980.

- Church: The Human Story of God. New York: Crossroad, 1990.

—. God Among Us: The Gospel Proclaimed. New York: Crossroad, 1983.

—. Interim Report on the Books Jesus \& Christ. New York: Crossroad, 1980.

—. The Schillebeeckx Reader. Edited by Robert J Schreiter. New York: Crossroad, 1984. 